\title{
Structural Analysis and Tectonic Investigation of Chamshir Dam Site, South West Zagros
}

\author{
Rezvan Khavari \\ Department of Geology, Islamic Azad University, Behbahan Branch, Behbahan, Iran \\ Email: Re khavari@yahoo.com
}

Received 18 February 2015; accepted 14 March 2015; published 18 March 2015

Copyright (C) 2015 by author and Scientific Research Publishing Inc. This work is licensed under the Creative Commons Attribution International License (CC BY). http://creativecommons.org/licenses/by/4.0/ c) (i) Open Access

\begin{abstract}
Geological factors play a major role in constructing and stability a dam. The study area is Chamshir Dam, which is located on the Zohreh River, $20 \mathrm{~km}$ southeast of Gachsaran City (southwest Iran). The satellite images are valuable means available to geologists for locating geological or geomorphological features expressing regional fault or fracture systems, therefore, the satellite images are used for structural analysis of the Chamshir dam area. As well, using the DEM and geological maps, 3D Models of the area have been constructed. Then, based on these models, all the acquired fracture traces data are integrated in Geographic Information System (GIS) environment by using Arc GIS software. Based on field investigation and DEM model, main structures in the area consist of Cham Shir syncline and two fault sets, the main thrust faults with NW-SE direction and small normal faults in NE-SW direction. There are three joint sets in the study area, both of them $\left(\mathrm{J}_{1}\right.$ and $\left.\mathrm{J}_{3}\right)$ are the main large fractures around the Chamshir dam. These fractures indeed consist with the normal faults in NE-SW direction. The third joint set in NW-SE is normal to the others. In general, according to topography, geomorphology and structural geology evidences, Chamshir dam has a potential for sliding in some parts of Gachsaran formation.
\end{abstract}

\section{Keywords}

DEM, Chamshir Dam, Satellite Images

\section{Introduction}

The assessment of the structural stability of gravity dams is an important part of the overall process on ensuring the safety of both new and existing structures such as faults, fracture zones and folding [1]. Geological factors 
play a major role in designing and constructing a dam [2], as they control the nature of geological formations and also provide the needed materials for construction. Many cases had occurred throughout the world where dam foundation rock mass conditions were not sufficiently known and the cost of construction and treatment greatly exceeded the original budget.

The Zagros fold-thrust belt in SW Iran is a part of the Alpine-Himalayan system which consists of a variety of structures with different sizes or geometries. In this paper, we try to evaluate stability of Chamshir Dam based on DEM and field investigations.

\section{Geological Setting}

The Chamshir dam site on the Zuhreh River is located in south-western Iran, about $20 \mathrm{~km}$ southeast of the Gachsaran city. The Zohreh River is one of the most important rivers in south of Iran. Its length is $490 \mathrm{~km}$ and its height from the source is $2850 \mathrm{~m}$. After flowing through the township of Behbahan, it joins the Persian Gulf. The geological formations in the study area, from oldest to youngest, are Gachsaran, Mishan, Aghajari, Bakhtiari and alluvial sediments. The Mishan formation along with the Gachsaran formation cover the western part of the dam reservoir and dam site [3] [4]. The Zuhreh River has created the long and narrow Chamshir gorge by erosion of biohermy limestone, thereby making it a suitable location for dam construction. The main lithology of the area consists of limestone and marl rocks of Mishan formation (Figure 1). The study area is in the Zagros folded area or external Zagros [5] and simply folded belt. Zagros folding compressional tectonic forces have created some faults and thrust faults having a NW-SE trend in the study area; the Dezh solayman thrust, Murd thrust and Chamshir fault area are the most important ones. Seismologically, it's located in the Zagros zone and has a similar behavior [4].

\section{Materials and Methods}

The satellite images are valuable means available to geologists for locating geological or geomorphological features expressing regional fault or fracture systems, therefore, the satellite images were used for structural analy-

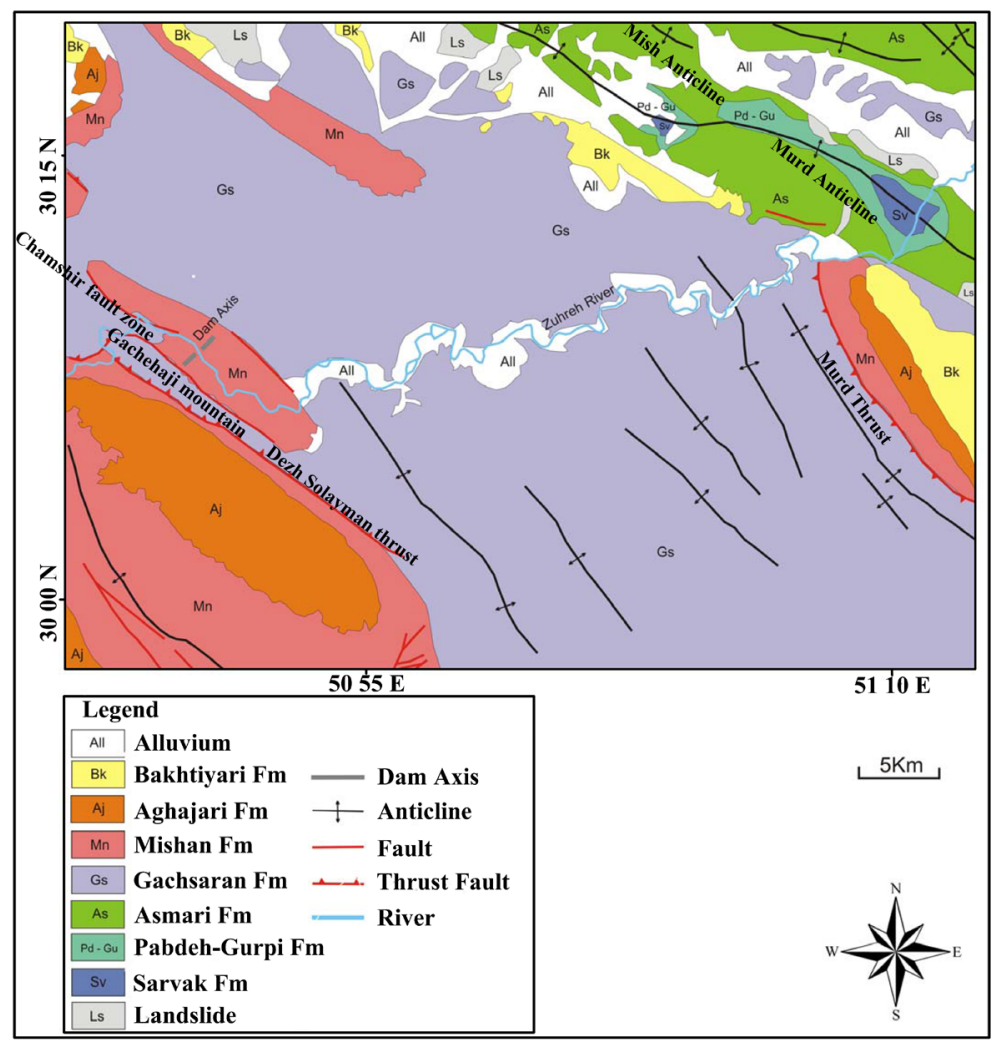

Figure 1. Geological setting of the study area. 
sis of the Chamshir dam area. Furthermore, in order to 3D analysis of geological structures in the area, a detailed Digital Elevation Model (DEM) has been constructed, using digital topographical maps. As well, using the DEM and geological maps, 3D Models of the area have been constructed (Figure 2). Then, based on these models, all the acquired fracture traces data were integrated in Geographic Information System (GIS) environment by using Arc GIS software. Using the hydrologic modeling functions in ArcGIS, it is possible to obtain the direction of surface water flow, slope value and aspect from the filled DEM (Figure 3). A Digital Elevation Model is used to determine which cells flow into other cells (the flow direction). However, if there are errors in the digital elevation model, using hydrologic analysis functions, it is possible to identify them and fill. The flow direction can obtain from this depressionless elevation model. In this study we have used $10 \mathrm{~m}$ grid cell DEM of Chamshir Dam. Its projection was the UTM zone 39N. The DEM was derived from the contour lines of the 1:25,000 topographic maps with $10 \mathrm{~m}$ contour intervals.

\section{Structural Analysis}

\subsection{Main Structures}

The Chamshir dam is built on Mishan limestone and marl rock units. Based on field investigation and DEM model, main structures in the area consist of ChamShir syncline (Figure 4) and two fault sets. The valley walls at the dam site are steep; the characteristics of bedding planes involve N80E/36SE in right abutment and N22W/26NE in left abutment. According to this value, Chamshir syncline axis is $16^{\circ} / 112^{\circ}$. In the Chamshir gorge the overall dip of bedding is about $10^{\circ}$ to $14^{\circ}$ and the dip direction chanbetween $88^{\circ}$ and $105^{\circ}$.

\subsection{Faults}

There are two fault sets; the main thrust faults with NW-SE direction and small normal faults in NE-SW direction. High dip angle normal faults with spacing 50 to $100 \mathrm{~m}$ and maximum displacement are the main cause of karstification in the area.

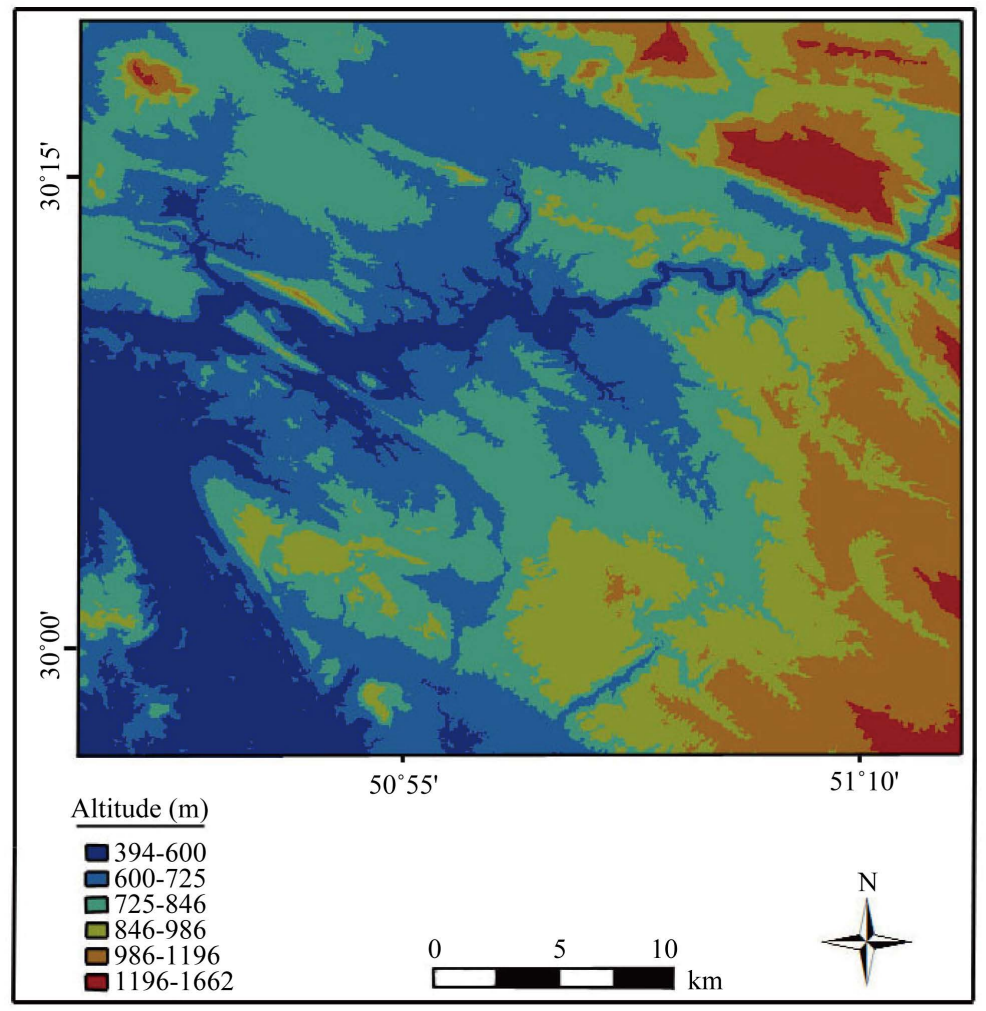

Figure 2. Classified digital elevation model of the study area. 

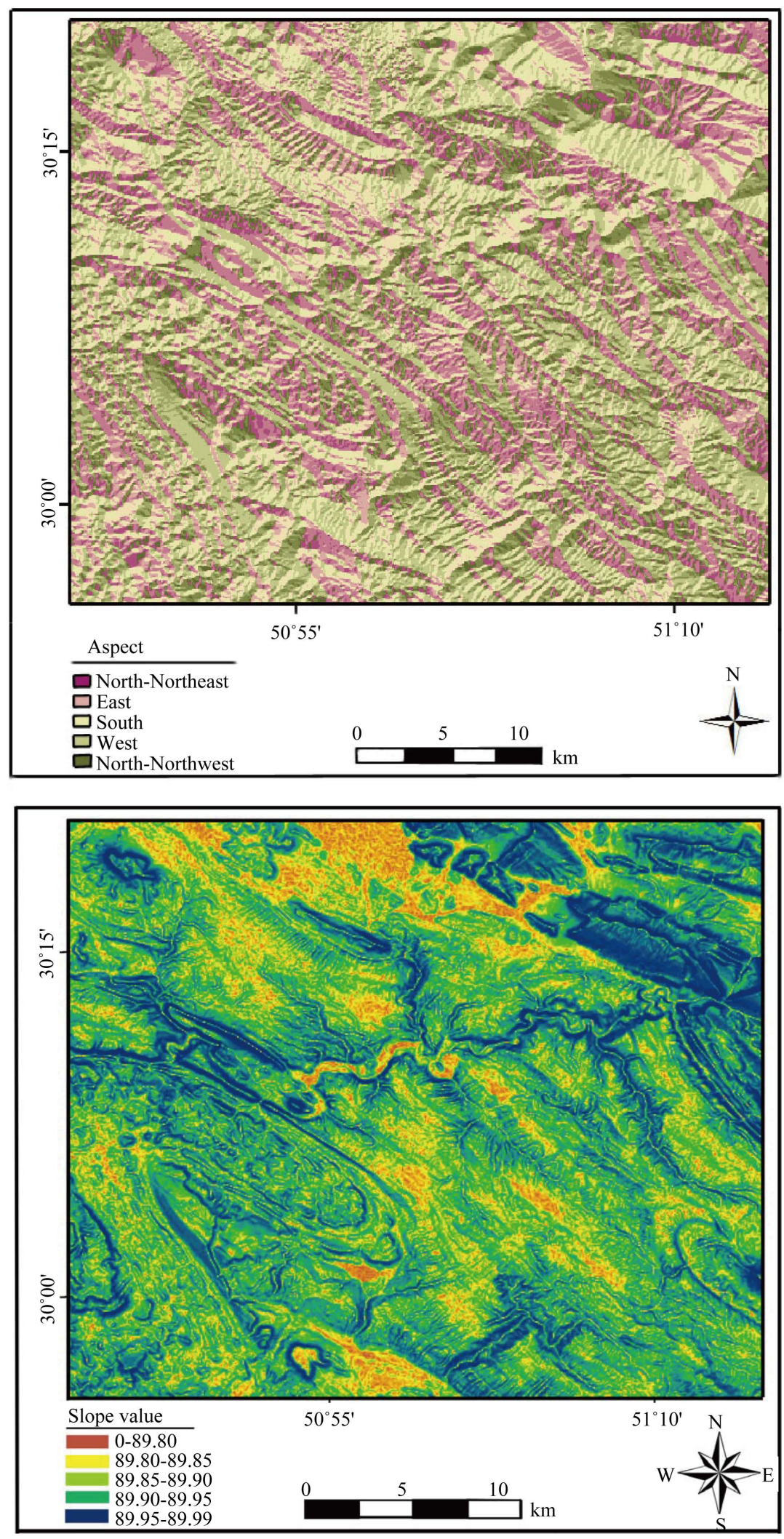

Figure 3. Aspect and slope values derived from digital elevation model of the study area. 


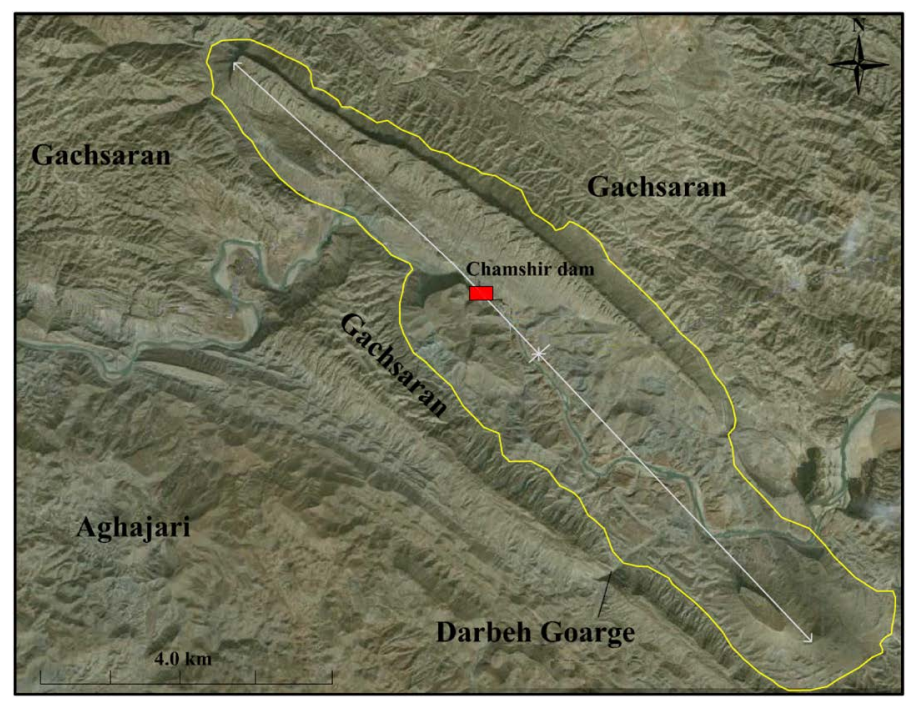

Figure 4. Chamshir syncline and different formations around the dam.

\subsection{Thrust Faults}

Dezh solayman and Kharabeh trusts with NE dip direction, are the main faults around the Chamshir syncline that are located in the SW and NE climbs of the syncline respectively. The role of the Dezh solayman in the study area is important according to field observation. The Gachsaran formation is uplifted along this fault from deeper parts to the surface. It has dissected some parts of the Mishan formation in the north-eastern branch of the Chamshir syncline and has consequently thrust the Gachsaran formation over the Mishan formation. The extensive tectonic pressure of the Dezh solayman created the important Chamshir fault area, this being the source of several springs throughout this area and the Dezh solayman. The Zuhreh rivers deviation from its direct pathway into the Chamshir fault area could also provide reasonable evidence of tectonic activity in the study area [4].

Kharabeh thrust, which can be a hanging wall branch of Dezh solayman, located the Gachsaran formation in front of Mishan units. Kardarigun mountain is the best place to represent the surface trace of this thrust (Figure $5)$.

\subsection{Normal Faults}

$\mathrm{F}_{1}$ and $\mathrm{F}_{2}$ are normal faults that are related to folding and indicate the main displacement in mountain climbs. $\mathrm{F}_{2}$ which is located in Darbeh gorge, changes the dip direction of bedding in both sides of gorge (Figure 6). Maximum displacement along these high angle faults is about $1 \mathrm{~m}$.

\subsection{Joint Systems}

Different locations in Mishan formation around the main axis have been considered for field studies. 0 discontinuities on the left and 85 discontinuities on the right abutments were measured and the results were represented in Contour diagram. There are three joint sets in the study area, both of them $\left(\mathrm{J}_{1}\right.$ and $\left.\mathrm{J}_{3}\right)$ are the main large fractures around the Chamshir dam. These fractures indeed consist with the normal faults in NE-SW direction. The third joint set in NW-SE is normal to the others (Figure 7).

\section{Discussion and Conclusions}

The Zagros fold-thrust belt in SW Iran is a part of the Alpine-Himalayan system which consists of a variety of structures with different sizes or geometries. Using the DEM and geological maps, 3D Models of the area have been constructed. Then, based on these models, all the acquired fracture traces data were integrated in Geographic Information System (GIS) environment by using Arc GIS software (Figure 8).

The assessment of the structural stability of gravity dams is an important part of the overall process on ensuring 

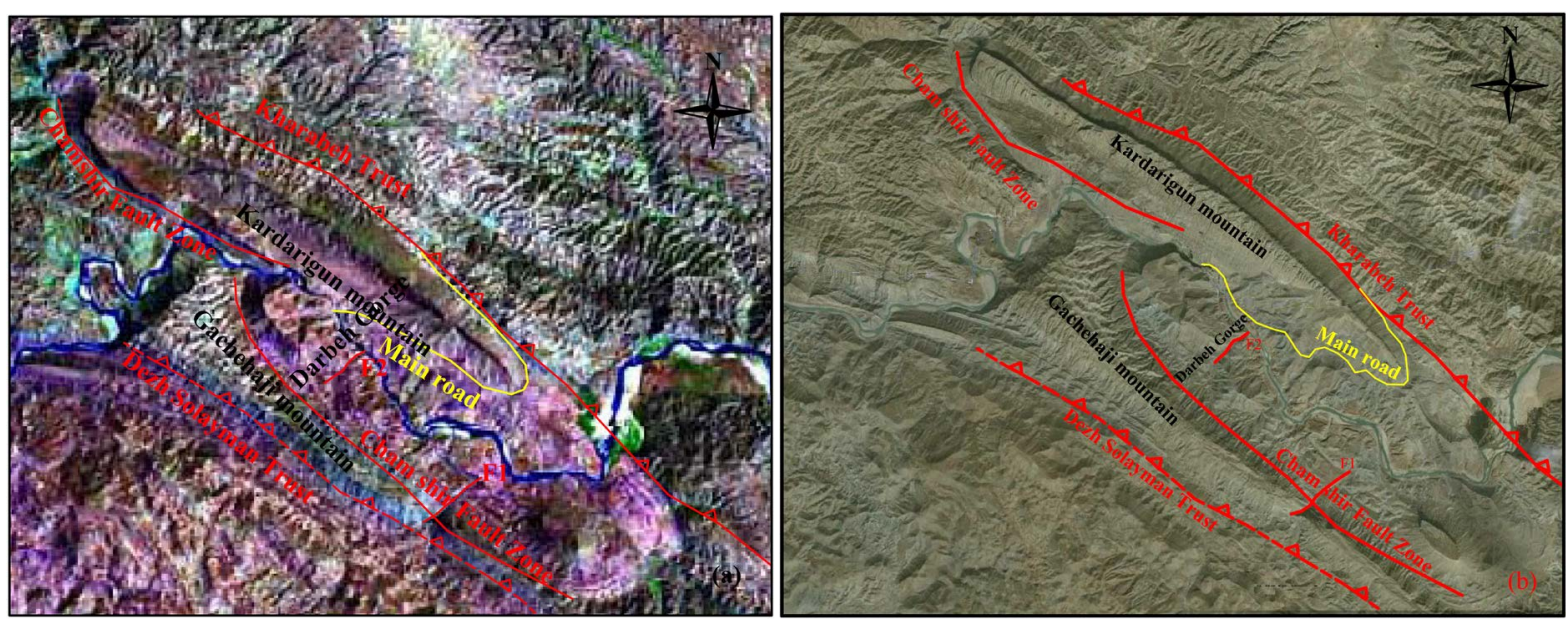

Figure 5. Location of Dezh solayman and kharabeh trusts around the Chamshir dam. (a) Landsat 7; (b) Google Earth.
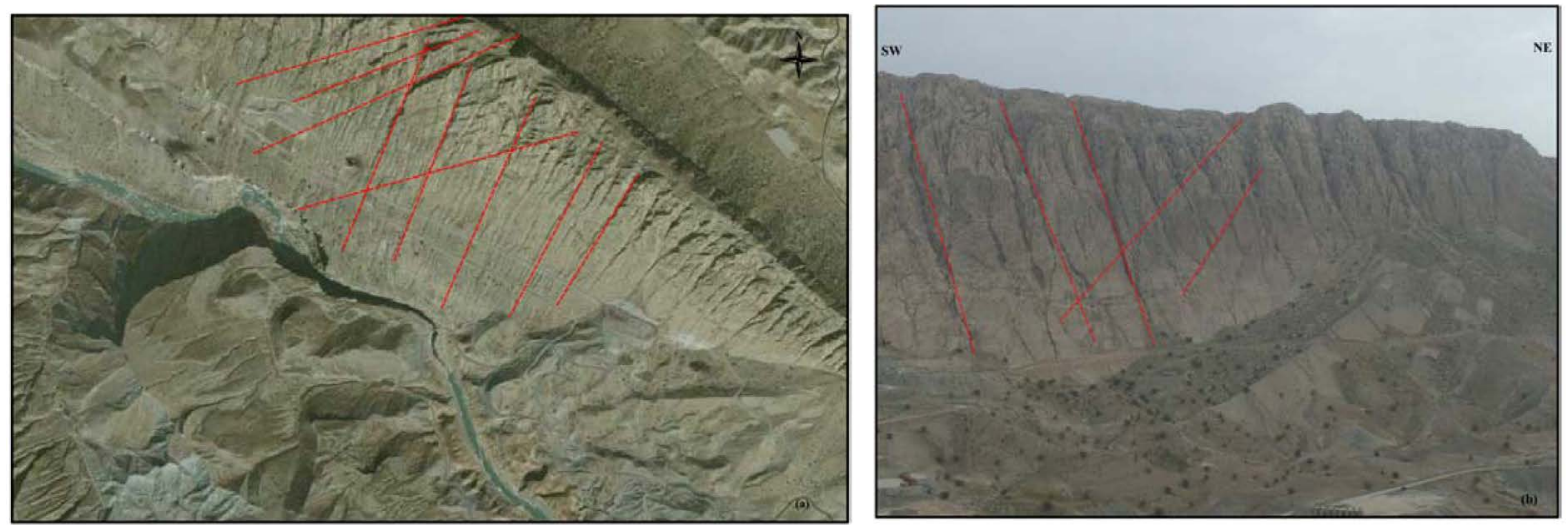

Figure 6. Normal faults in NE abutment of Chamshir dam. (a) Satellite image; and (b) Field image.

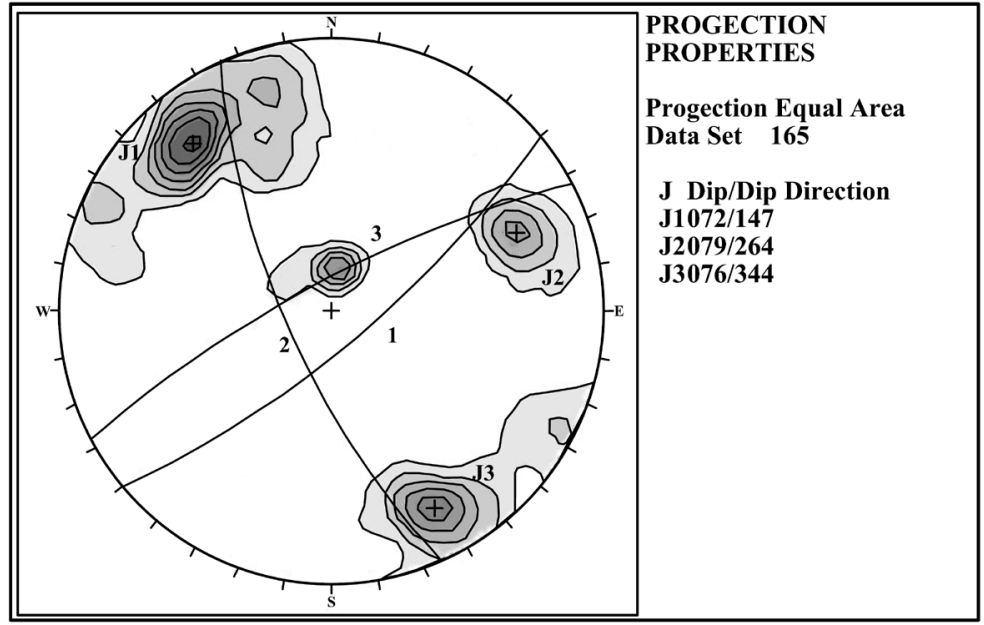

Figure 7. Contour diagram of joint sets in dam area.

the safety of both new and existing structures such faults, fracture zones and folding [3]. Geological factors play a major role in designing and constructing a dam as they control the nature of geological formations and also provide the needed materials for construction [2].

The Chamshir dam is built on Mishan limestone and marl rock units. The valley walls at the dam site are steep 


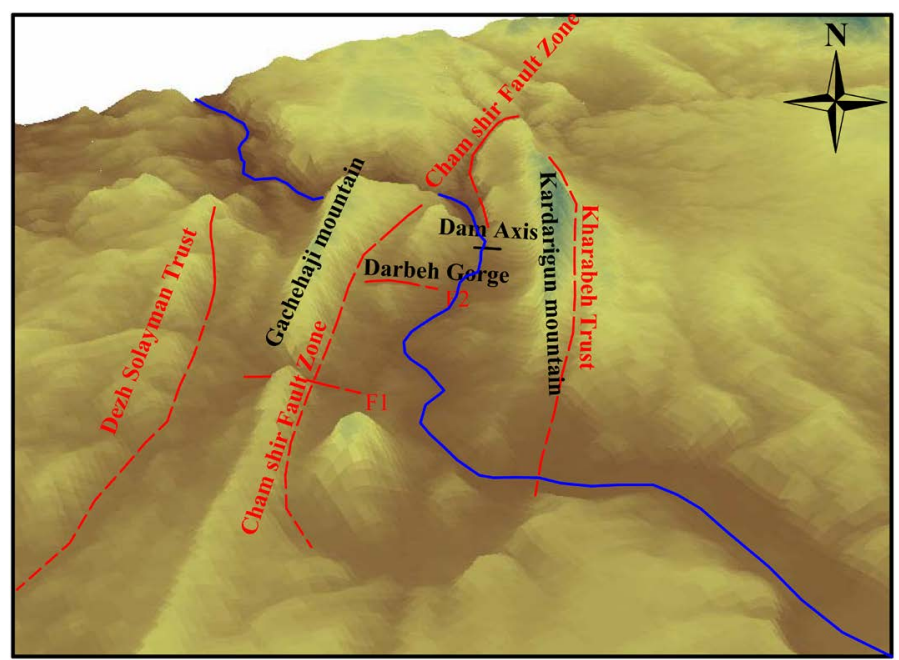

Figure 8. Correlation of DEM and structures in the study area.

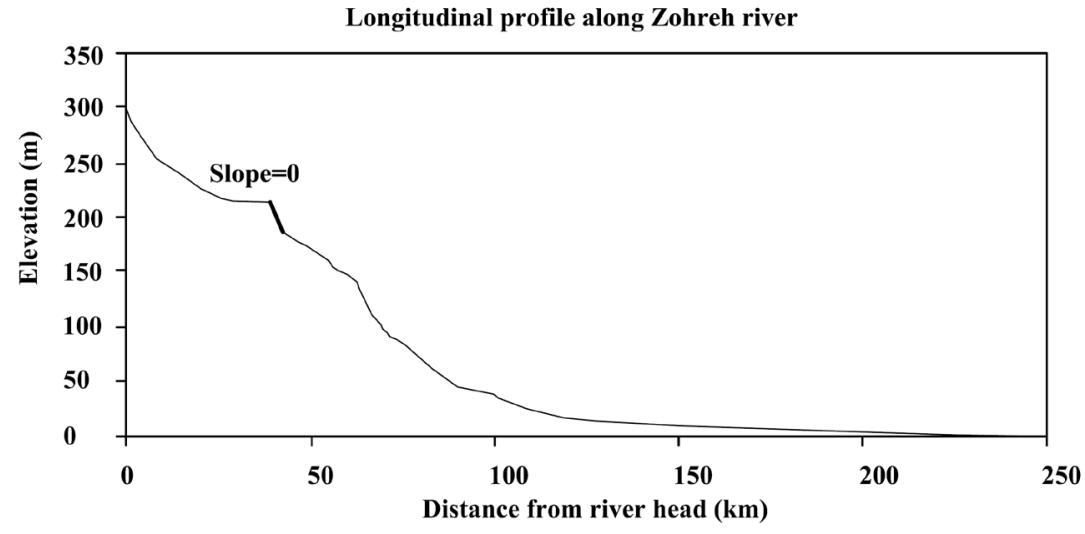

Figure 9. Longitudinal profile of Zohreh River derived from DEM, represented the slope value in Dam site and knickpoint location along river just after dam.

and according to the longitudinal profile along Zohreh River, there is a knickpoint with $100 \mathrm{~m}$ length in Mishan limestone and marl rocks (Figure 9). Based on field investigation and DEM model, main structures in the area consist of Chamshir syncline and two fault sets, the main thrust faults with NW-SE direction and small normal faults in NE-SW direction. High dip angle normal faults with spacing 50 to $100 \mathrm{~m}$ and maximum displacement are the main cause of karstification in the area. Three dominant discontinuity sets were identified on the left and right abutments of the proposed dam site, both of them $\left(\mathrm{J}_{1}\right.$ and $\left.\mathrm{J}_{3}\right)$ were the main large fractures around the Chamshir dam. These fractures indeed consist with the normal faults in NE-SW direction. The third joint set in NW-SE is normal to the others. According to topography, geomorphology and structural geology evidences, Chamshir dam has a potential for sliding in some parts of Gachsaran formation.

Overall, this paper indicated that joint inclination was the most important parameter affecting rock mass instability and some parts of both abutments, where Gachsaran formation was exposed, were instable.

\section{Acknowledgements}

This work was supported by the Behbahan branch of Islamic Azad University. We would like to thank this department.

\section{References}

[1] Tatone, B.S.A., Lisjak, A., Mahabadi, O.K. and Grasselli, G. (2010) Evaluation of the Combined Finite-Discrete Ele- 
ment Method for the Assessment of Gravity Dam Stability. Proceedings of the Canadian Dam Association Conference, Niagara Falls, 2-7 October 2010, 248-260.

[2] Ichikawa, K. (1999) Geological Investigation of Dams. Proceedings of 2nd Asian Symposium on Engineering Geology and the Environment, Malaysian National Group, Bangi, 44-57.

[3] Torabi-Kaveh, M., Heidari, M., Zarei, H.R. and Ghiasi, M.B. (2010) Engineering Geological Investigation of the Foundation of the Chamshir Dam Site by Use of DMR Classification (Iran). The 7th International Symposium on Eastern Mediterranean Geology, University of Çukurova, Adana, 18-22 October 2010, 129-136.

[4] Torabi-Kaveh, M. and Heidari, M. (2011) An Engineering Geological Appraisal of the Chamshir Dam Foundation Using DMR Classification and Kinematic Analysis, Southwest of Iran. Earth Sciences Research Journal, 15, 129.

[5] Stocklin, J. (1968) Structural History and Tectonics of Iran: A Review. American Association of Petroleum Geologists Bulletin, 52, 1229-1258. 